\title{
Representing Future Generations: Political Presentism and Democratic Trusteeship
}

\section{Citation}

Thompson, Dennis F. 2010. Representing future generations: political presentism and democratic trusteeship. Critical Review of International and Political Philosophy 13(1): 17-37.

\section{Published Version}

doi:10.1080/13698230903326232

\section{Permanent link}

http://nrs.harvard.edu/urn-3:HUL.InstRepos:9464286

\section{Terms of Use}

This article was downloaded from Harvard University's DASH repository, and is made available under the terms and conditions applicable to Open Access Policy Articles, as set forth at http:// nrs.harvard.edu/urn-3:HUL.InstRepos:dash.current.terms-of-use\#OAP

\section{Share Your Story}

The Harvard community has made this article openly available.

Please share how this access benefits you. Submit a story.

Accessibility 


\section{Representing future generations: political presentism and democratic trusteeship}

Dennis F. Thompson*

Department of Government, Harvard University, USA

Democracy is prone to what may be called presentism - a bias in the laws in favour of present over future generations. I identify the characteristics of democracies that lead to presentism, and examine the reasons that make it a serious problem. Then I consider why conventional theories are not adequate to deal with it, and develop a more satisfactory alternative approach, which I call democratic trusteeship. Present generations can represent future generations by acting as trustees of the democratic process. The general principle is that present generations should act to protect the democratic process itself over time. They should try to make sure that future citizens continue to have competent control over their collective decision making.

Keywords: future generations; democracy; representation; justice

Democracy is partial toward the present. Most citizens tend to discount the future, and to the extent that the democratic process responds to their demands, the laws it produces tend to neglect future generations. The democratic process itself amplifies this natural human tendency. These characteristics of democracy lead to what I call its presentism - a bias in the laws in favor of present over future generations.

Democracy's presentism is not entirely unwelcome. Compared to other forms of government, democracy is not disposed to sacrifice citizens or a whole generation for some distant future goal. It is less vulnerable to the claims of utopian idealists, religious zealots, or radical revolutionaries who call for great sacrifices from the present generation to bring about even greater good for the future of mankind. It is a virtue of democracy that it pays attention to

*Email: Dennis_Thompson@ksg.harvard.edu 
actual citizens and seeks to hold actual rulers accountable for the actions they take on behalf of citizens.

Nevertheless, this virtue of democracy becomes a vice when the good of future citizens are at stake. Presentism manifests itself in laws that neglect of long-term environmental risks, the consequences of genetic engineering, problems of population growth, and development of the democratic process itself. It also is evident in effects in the nearer term in laws that favor the elderly at the expense of children. Examples include the disproportionate allocation of resources for health care of the elderly and the financing of social security out of current taxes. In these and other similar instances, the persons who are most adversely affected are not yet citizens (and therefore have no voice). The policies are not sustainable at a level that would enable the young to enjoy similar benefits when they grow old.

Democracy itself affirms that the citizens bound by laws should have a voice in making them. Yet future citizens who will be bound by the laws cannot have such a voice. Democracy's conventional way of addressing the problem of those who do not have a voice is to grant greater opportunities for participation and to institute more extensive representation. But making democracy more inclusive — expanding citizenship and enhancing representation — would not help future citizens. They do not have a voice because they cannot be citizens now. Yet they have to live with the consequences of the laws made by the citizens of an earlier generation. They may try to change the laws when their time comes, but that may be difficult or futile. The effects of many laws are irreversible. The damage may have been done. Critical resources may have been depleted, and environmental treasures spoiled. The political institutions needed to cope with the damage may have been corrupted or weakened.

If future citizens cannot be present now, how should they be represented? This question has not traditionally been a concern of political theorists or public officials. Governments did not 
expect most of their laws and policies to affect distant generations. Even when they did, they often could not foresee what the effects would be. The effects of laws now reach further into the future than ever before, and knowledge about those effects is greater than ever before. The problem of representing the unrepresentable - those who are bound by laws but cannot have a voice in making them - is therefore increasingly urgent. It poses a practical challenge, but it also raises some neglected and distinctive theoretical issues.

To explore the question of the representation of future generations, I identify the characteristics of democracies that lead to presentism, and examine the reasons that make it a serious problem. Then I consider why conventional theories are not adequate to deal with it, and try to develop a more satisfactory alternative approach, which I call democratic trusteeship.

\section{Democratic myopia: why democracies neglect the future}

Democracy's neglect of future citizens has at least four sources. First, there is the natural human tendency to prefer the immediate to the distant, both in what one fears and what one desires. The tendency shows itself in politics as in ordinary life. ${ }^{1}$ Political leaders, like ordinary people, are not naturally inclined to defer gratification. Democratic government is supposed to be responsive. To the extent that it transfers these psychological tendencies to the political process, it produces laws and policies that reflect this bias toward the present. (Notice: this bias is not the same as self-interested motivation. Even if one treats the future as an extension of one's self, one tends to be biased in favor of the present self.)

The second reason for neglecting future generations appeals to the oldest and still one of the most influential justifications for the principle that representatives should be responsive to their constituents. The justification holds that the individuals who will be affected by the laws are the best judges of the laws. As John Stuart Mill wrote: 'each is the only safe guardian of his own 
rights and interests' (Mill 1977, p. 404). ${ }^{2}$ Adopting this justification for citizen participation, citizens and their representatives should judge a law according to how they experience, or expect to experience, its effects. This rationale does not assume that citizens are self-interested or that representatives are only delegates, but it does imply that representatives should give great weight to citizens' views about the effects of the laws on them and people like them living in circumstances like theirs. Some other conceptions of democracy are even more closely tied to the views of the present citizens. Any conception — such as interest group pluralism, in which the preferences of citizens are aggregated to produce the collective result-is inevitably presentoriented by virtue of its reliance on the demands of existing citizens.

The third source of the neglect of the future stems from the fact that democracy is government pro tempore. The rulers exercise power for a limited period of time, after which they stand for reelection and reappointment, or retire from office. Although one can imagine a democratic government (with majority rule) that is absolute (as in Hobbes's 'democracy') (Hobbes 1991, Bk. II, ch. XIX), political power in nearly all actual democracies is subject to temporal limits. Even an absolute majority can be eventually overruled by a subsequent majority. Consequently, even (or especially) well-intentioned rulers and representatives try to make a difference sooner rather than later. They try to pass laws and policies that produce results within the limit of their time in office. The supporting institutions of democracy, such as the press, also reflect (and because of their own dynamics, reinforce) this appetite for the immediate.

Finally, there is a tendency in most modern democracies today to favor the older age group. Because this group are more numerous, and also because some of them exploit spurious age discrimination claims, they are privileged in law and public policy. At first one might think that the bias for the elderly is just the opposite of presentism. The policies in question provide more for the needs of citizens in the later than earlier stages of life and in this sense provide for 
the future. But that description applies only when we look at the time horizon from the perspective of an individual. From the perspective of the democratic majority at any particular time, the decision to favor the older generation is actually a form of presentism. Social Security in the U.S. is a telling example: it creates tax obligations for not only younger citizens but children yet to become citizens in order to provide for the older age group at any particular time. This might be a fair distribution over time, were it not for the fact that the younger age group cannot expect to receive proportionate return for the benefits it is providing for the current elderly generation. Laws against mandatory retirement are another case of discrimination in favor of the old (at least where the number of highly desirable positions is limited and unlikely to expand over time).

Presentism - in both the form that neglects citizens not yet born, and those who are too young to be citizens - should be distinguished from the short-sightedness that afflicts the same individuals over time. Some of the same pressures toward presentism also tilt laws and policies against the long-term interests of current citizens. But this is a different problem; it is more a failure of prudence than morality. It can be addressed by showing that sacrificing now for a future benefit is in the self-interest of some individual or group. The individual or group of identifiable individuals can usually recognize that they will benefit from the sacrifice later. Younger citizens may vote for policies that benefit older citizens because they will themselves be older citizens someday. The problem of future citizens cannot be addressed in this way because the individuals who sacrifice are not the same as those who benefit.

\section{Democratic evasions: why presentism is a serious problem}

Many theorists assume that the claims of future citizens can be addressed within the framework of conventional democratic theory and practice. ${ }^{3}$ The theorists offer several reasons for assuming 
that the claims of future citizens do not require any special attention, and in most cases should be discounted. One common approach starts with these observations. The composition of the demos changes gradually. ${ }^{4}$ Citizens and their representatives do not leave the democratic stage all at the same time. They continue to have some connections to those who follow. Citizens care about their children and grand-children, and both citizens and their representatives care about sustaining democratic institutions. But this argument from generational connections is not sufficient. The further we look to the future, the weaker and more indeterminate the connections. Many policies now have their most significant effects a century or more in the future, when the connections between present and future perspectives are tenuous.

Another set of arguments for discounting future generations suggest, not that it is unnecessary to give any special attention to future generations, but rather that such attention is unjustified. One reason it is thought to be unjustified is that future generations in all democracies are likely to be much better off than any present generation, because they will benefit from the accumulated knowledge and technological capital of previous generations. They should be able to take of themselves because we have given them more than we had.

This view fails to take into account the large and often irreversible harms that current generations can inflict on future generations. The destruction of the earth's atmosphere as a result of global warming is only one of many such environmental harms that almost certainly cannot be reversed. We can assume that technological progress will provide future generations better ways of coping with the harm than those we now have, but we should not assume that they should regard the accumulated knowledge they receive reasonable compensation for the massive damage we have done.

Even damage to political institutions is not so easily repaired as is often assumed. The health of democracies depends not only on explicit practices and formal laws but also as much on 
implicit customs and informal norms that are developed fitfully over time and often with difficulty. Some of the traditions may constrain future generations too much, and some too little. Achieving the right balance is a long and difficult project that requires that citizens continue to believe in the goals of democracy even while their own governments fall short. Once the confidence of citizens in their form of government begins to erode, it may be impossible to restore it.

Giving special attention to future generations is said to be unjustified for another reasonone that seems more morally attractive because it refers not to everyone in a current generation but only the most disadvantaged. The argument is that it would not be fair to transfer resources from the relatively disadvantaged in the present to the relatively disadvantaged in the future. If justice requires that we concentrate on the least advantaged, then the claims of the present generation in the less developed nations would seem to be more compelling.

This argument rests on a mistake that is all too common and distorts the analysis of problems of global justice as well as future generations. The mistake is to separates too sharply the claims of foreign and future citizens. Their identities and therefore their moral status is not so distinct as many theorists assume. The further we look into the future, the less plausible it is to keep the question of foreign and future citizens separate. The citizens of our future democracy are just as likely to be descendants of some other present democracy or some present non-democracy. Even if the states remain the same (which is unlikely in the further future), the citizens of any particular future state are not any more connected to any current democracy than the citizens of some other future state. Even if we tried, we could not completely limit our efforts to help future citizens to only those who will be living in our own state in the future. Even from the perspective of the present, boundaries between states begin to dissolve the further into the future we look. 
Because present boundaries matter less in the future, they should also matter less in any decision about how the claims of future citizens should be weighed in the present. This may mean that developed nations should provide more aid than they do now to developing nations before worrying about the debt their own citizens will carry in the next several generations. But it does not mean that the claims of more distant generations should be radically discounted. It does not provide any warrant for ignoring the problem of future generations, or discounting their moral claims.

Perhaps the most common reason for neglecting or discounting future generations is uncertainty. Those who put forward this reason may concede that it would be necessary and desirable to give more respect to their claims if we had any rational basis for predicting what they will be, or what weight we should give to them. But it is difficult if not impossible to trace the causes the harms that present states visit upon future states, and no less difficult to make reliable predictions about the policies intended to remedy those harms. Uncertainty about the needs of future citizens is therefore great. We cannot be confident now that they will, for example, want national parks and green spaces, or even (if we look far enough ahead) whether they will need renewable fuels. Under conditions of such uncertainty, any plausible discount rate will give the claims of distant future generations no weight at all.

The argument from uncertainty has considerable force, and militates against any theory or principle that would try to specify a wide range of the needs and wants of future generations, and instruct representatives to pursue policies to satisfy them. But in the radical form in which it is often stated, it is not plausible. We can be fairly confident about some of the harms we are causing or to which we are contributing. Even in the remote future, we can reasonably assume that citizens will not want to live with toxic chemicals, foul air, and chronic disease. ${ }^{5}$ More importantly for the conception of representation I suggest below, we can assume that future 
generations will need a way of deciding collectively how they want to cope with these harms, and what rights and goods they want to pursue or forgo under these conditions.

The argument from uncertainty, then, may cast doubt on any approach that would promote the welfare or the rights of future generations across the whole range of welfare or rights, but it does not justify ignoring all of their potential claims. More positively, it provides a reason to protect their capacity for making their own collective decisions. The very uncertainty that warrants doubts about what their needs will be supports an obligation to try to make sure that they have a process for deciding together what their needs are and how they should be met.

\section{Democratic justice: why conventional theories fail}

Most democratic theorists and most democratic politicians would agree that the citizens of a particular democracy should act justly toward to future citizens. For if future citizens cannot be present in the current democratic process, and if we cannot know much about what their views will be, it would seem that the best we can do now is to act on our own principles of justice, and treat them fairly from our own perspective. Justice is indeed an important consideration in deciding how future citizens should be represented, and the philosophical literature on this subject is clearly relevant to this project.

Unfortunately, conceptions of justice do not work well when extended to future generations. They do not work well or at all when they are applied to the distribution of benefits and burdens over many generations. ${ }^{6}$ The basic problem is that future citizens cannot be parties to the actual or hypothetical agreement that is typically assumed to be necessary to generate the principles of justice. The principles that are chosen will determine who will exist (they will affect the distribution of population over time, for example). It is not coherent to include as parties to the agreement individuals who will not exist if the agreement is concluded. 
The most systematic search for a place for future generations in a theory of justiceexemplified in the work of John Rawls - shows how difficult the task is. In the initial full-length version of his theory, Rawls had trouble formulating within the 'original position' a justification for a just savings principle, which requires earlier generations to save for later generations (Rawls 1971, pp. 284-93). ${ }^{7}$ In the original position, individuals are to reason, on the basis of our selfinterest, behind a 'veil of ignorance' that prevents them from knowing who in particular they are, or in what generation they happen to live. Under these conditions, the reasons any individual gives would not be biased in his favor, but they would not appeal to any moral considerations.

What role could future generations play in reasoning under these conditions? As part of their self-interest, individuals could take into account the interests of their immediate descendents but they would have no reason to consider the interests of more remote generations. The veil of ignorance leads people to maximize their interests (and those of their immediate descendants). As one critic points out, 'since nothing can be done to change the past, there is no advantage to the people in the original position in choosing a principle that requires any net savings (or indeed, one might add, prevents them from running things down) unless they actually care about the welfare of the next generation' (Barry 1989b, p. 200). Even if we assume that people in the original position care about the well-being of their children and their children's children, their concern for future generations must diminish rapidly as they contemplate each passing generation. From a moral point of view the concern diminishes too rapidly. But there is no way to prevent its premature expiration without introducing into the original position the very moral considerations it is designed to do without.

In a later version of his theory, Rawls puts some of these moral considerations back into the original position. To choose a just savings principle for future generations, we are now to apply a kind of golden rule to savings: do unto future generations as you would have past 
generations do unto you (Rawls 1993, p. 274; 2001, pp. 159-60). ${ }^{8}$ We can justify a just savings principle 'because society is a system of cooperation between generations over time' (Rawls 1993, p. 274). The parties in the original position 'can be required to agree to a savings principle subject to the further condition that they must want all previous generations to have followed it' (Rawls 1993, p. 274). This argument, and the kind of reasons it tells representatives to give, moves quite a distance from the self-interested reasoning of the original position. It begins to look like a trustee conception of representation applied to the original position.

The course of Rawls's journey—from constrained self-interest to generational reciprocity - carries a lesson for any democrat who would seek to protect future generations. They are not adequately represented if representatives are held accountable only for pursuing the interests of current constituents and their near progeny. To be sure, if these interests are defined to include 'moral interests', and constituents are said to have a moral interest in the well-being of future generations, then accountability to the interests of constituents will ensure that representatives care about future generations. But this move either smuggles in a moral argument under the guise of self-interest, or treats the concern for future generations as purely contingent on the interest the current generation takes in them. We need a principle that holds representatives accountable not only for satisfying the interests of their constituents but also for acting in a way that can be justified to future generations.

'Do unto future generations as you would have past generations do unto you' could provide a good starting point for representatives who seek to protect the future. But the principle would have to be interpreted in a way that does not refer to specific individuals, and such an interpretation would be difficult to fit within the perspective of a representative as an agent (trustee or delegate) acting on behalf on constituents (present or future). The reason that the principle should avoid reference to individuals is so that it can escape the dreaded non-identity 
problem (Parfit 1983, pp. 166-179; Parfit 1986, pp. 351-79). ${ }^{9}$ Decisions that representatives make now cannot be said to harm any particular individuals in the future because those individuals would not exist at all but for these decisions. For example: risky or depletive energy policies are not against the interests of people in the further future. No matter how depletive our present policy, it does not make anyone in the further future worse off because without those policies they would not have been born. To oppose depletive energy policies, then, we need an argument that does not appeal only to the interests of future persons. What needs to be represented are not the claims of future individuals but something like the value of human flourishing in the future. But the ordinary conception of political representation - which assumes a relationship between a representative and identifiable constituents_-does not fit well with such an abstract value. Of course actual constituents could themselves value human flourishing in the distant future, and demand that their representatives pursue this value now. But neither the constituents nor the representatives would then be acting on principles found in conventional theories of justice.

It might be thought that utilitarian conceptions could do better. After all, utilitarians are criticized for not respecting individuals enough. They are charged with sacrificing the utility of some individuals to achieve a greater social utility, in which the individuals whose welfare is promoted are fungible. Their identity is irrelevant, and hence their non-identity creates less of a problem. Furthermore, utilitarianism does not rely on agreements among individuals, or prohibitions against wronging individuals. It does not have to assume that any wrong is done to particular individuals in the future. It seeks to determine only whether some future state of affairs is preferable (produces greater utility) to another state of affairs (produces lesser utility).

However, to the extent that utilitarian goals are detached from identifiable individuals, they provide less motivation for citizens (and therefore their representatives) to pursue them. Utilitarianism undermines the reasons that most citizens find most persuasive for respecting 
future generations - making individuals in the future worse off. In practice, utilitarianism could even undermine itself by causing citizens to give future generations less than what the correct utilitarian calculation would require. (This possibility has led some utilitarians to suggest that the non-identity problem should not be widely publicized (Parfit 1983, pp. 175-6 and Parfit 1986, pp. 451-2).

Another problem with utilitarianism at least in some forms also partly stems from its focus on social welfare rather than the welfare of each individual. A principle that would maximize total welfare over time implies that population should be maximize (Ryberg et al, 2006). As long as the welfare of any particular individual is positive however low the level, the principle calls for increasing the number of individuals in the world. We should continue to not only allow but encourage population growth, even at the cost of great reductions in the level of welfare of future citizens.

The problem of representation of future generations cannot be adequately addressed, then, by appeals to theories of justice or utility applied in the present. Even if principles of justice or utility can provide some guidance for thinking about future citizens, they need to be supplemented by principles specifying how the anticipated views of those citizens should be taken into account when the principles of justice run out or the principles of utility are contested. The problem of representation for future citizens is not entirely coincident with the problem of justice or utility. Democratic representation poses a prior (independent) question: who should have a voice in deciding whether laws are just or policies promote utility? Democrats believe that actual citizens should have a voice and should be represented in the making of laws whether or not they if they hold the correct principles of justice or the right concept of utility. They should have a voice because disputes about some policies do not depend entirely on questions of basic justice or social utility, because there may be reasonable disagreement about what is just or utile, 
and because sometimes even when what justice or utility demands is clear the values of democratic autonomy and legitimacy should prevail.

To respect the rights and goods of future generations, we need more than an a temporal extension of principles of justice and utility. We need a revised conception of representation that enable democracies to represent future citizens who are not now present. We need a conception of democratic representation for citizens-to-be.

\section{Democratic trusteeship: how the future can be represented in the present}

If future generations cannot be present now, how can they be represented? Present generations, I suggest, can represent future generations by acting as trustees of the democratic process. The general principle of the trustee conception that we need to develop is that present generations should act to protect the democratic process itself over time. They should try to make sure that citizens continue to have competent control over their collective decision making. The principle does not seek to maximize popular control as such. That is not a plausible aim over time. It would imply that a earlier majorities could place no constraints on later majorities at all, even those that later majorities wish they had. It is also not a desirable aim. Popular control is ultimately valuable only insofar as expresses a genuine will, not transient impulses or uninformed preferences. The principle should permit only constraints that are necessary to make a majority at any particular time competent in the sense of having the capacity to express a sufficiently settled and an adequately informed judgment. The capacity depends on the continuing existence of robust social and political institutions sufficient to support at least a minimal form of democratic government

The principle can take at least two different forms - one less demanding than the other.

The first (less demanding) version holds that citizens or their representatives in democratic states at any present time should seek to preserve a democratic process that gives future citizens at least 
as much capacity for collective decision making as present citizens have. This can be seen as a political adaptation of the Lockean principle regarding property — which grants a right to appropriate land 'where there is enough, and as good left in common for others' (Locke 1965, §27). Present democratic sovereigns should leave their successors 'enough and as good' democratic sovereignty as they themselves enjoy.

If we believe that the control that citizens now enjoy is inadequate, we may wish to adopt a more demanding version of the principle. It would stipulate that any current political generation should seek, up to the point that control over their own decision making begins to decrease, to maximize the control that future generations will enjoy. Although this version would more reliably overcome the dead hand of past generations, it may also place excessive and unrealistic demands on earlier generations.

It is not necessary to decide between the two versions in order to develop the essential ideas of the trustee conception I am proposing. On either version of the principle, representatives (and their constituents) in the present should protect the democratic capacity of future representatives (and their constituents). The idea underlying both is that on whatever grounds any present democracy bases its authority, it should protect the democratic capacities of future democracies.

This trustee conception does not say simply — as a traditional trustee theory would — that representatives (or citizens) should use their best judgment and act in the interest of future citizens (Pitkin 1967; Thompson 2004, ch. 5). The future-oriented representatives are trustees of the democratic process, not the whole range of interests or welfare of future citizens.

Representatives may not know the preferences, needs or life plans of future citizens, or even the best form of democracy for a future society. But they can know enough to try to preserve the conditions that would empower future citizens to make collective choices democratically. 
Compared to theories of justice, this conception of representation has the advantage of requiring no reference to specific individuals, and little knowledge of the preferences or life plans of individuals or societies in other cultures or in the future. Present citizens would not be in the position of trying to imagine what future citizens might need while making policies that would determine whether future citizens exist. Compared to theories of utility, this conception does require complex predictions about the wide range of needs and desires that future citizens might have and the consequences of policies that future representatives might adopt. The principle (in either form) assumes that there will be a democratic state to which future citizens will belong, but not that it will have the same character as any present state. The principle assumes only that future citizens should have a voice in the making of the laws by which they are bound, and should be able to hold accountable officials who carry out those laws. To have an effective voice and to exercise effective accountability, they will need a democratic process that preserves their competence to control their government. But this is a less substantive - and less constrainingassumption than those required by most other theories that seek to protect future generations, including general theories of justice and utility.

It may be objected that we do not know what kind of democratic process future citizens will want - any more than we can know what kind of justice or utility they will seek. They may reasonably prefer an electoral system based on proportional representation rather than a winnertake-all majoritarian system. They may favor more direct forms of democracy (greater use of initiatives, recall, referenda). They may want to modify a presidential type of government in the direction of a parliamentary type. These and many other forms of government are quite compatible with the trustee conception I am suggesting. Except for the constraints necessary to promote competent control, the conception does not prescribe a particular form of democracy. Indeed, it implies that as far as possible a current democratic majority should leave open the 
possibility of changes to other forms, including those, such as the adoption of a different electoral system, that would alter the definition of the majority itself.

Some people who are prepared to accept the principle of democratic trusteeship may doubt whether it can be of any use in practice. One doubt is quite general: it expresses scepticism about the relevance of theory for practical questions of institutional design. All theory can do is to present and justify principles: it has nothing to contribute to the hard practical work of designing institutions to realize those principles. To be sure, theory does not usually offer much specific guidance to institutional designers, even those who make constitutions. But it can identify values that are likely to be neglected and prescribe priorities that should be adopted in creating and reforming institutions. As in the preceding analysis, which was mostly theoretical, it can show why some arguments standing in the way of institutional change should be rejected, why some theories claiming to provide sufficient guidance are mistaken or incomplete, and why widely recognized institutional biases (what I called democratic presentism) should be resisted.

Still, some may still doubt whether the theoretical aims can be realized at all, whether there any institutional forms that could distinctively promote the values and priorities to which it calls attention. The practical problems is that all representative institutions suffer from two kinds of risks - that representatives will have too little power to serve their constituents, or they will have too much power to serve only themselves. The trustees of the democratic process that I favour may not have sufficient power to ensure that future citizens receive the respect they should; or if the trustees have enough power, they will use it for their own political purposes (or for ends other than the democratic capacities of future citizens). In designing the institutions of trusteeship, we need to be concerned about both possibilities, but the first is the more probable. In most current and foreseeable democracies, trustees of the future are not likely exercise great power. 
No single representative institution can guarantee that future citizens will receive the attention they should. Certainly the constituents who are supposed to be represented cannot actually hold anyone accountable. By the time some of them come into existence, their representatives will have passed from the scene. Nevertheless, it may be possible to create a role whose occupant is dedicated to looking out for future generations. The representatives would be accountable to the requirements of the role, which would express the perspective of future citizens. The role requirements would in effect stand as a surrogate for future citizens. As we know from experience and from studies of role behavior in a variety of institutions, a role can change its occupant's attitudes and actions, sometimes for the better (see Biddle 1986, pp. 84-5; Ilgen and Hollenbeck 1991; Strijbos et al 2003; Gehlbach 2004). Roles can be designed so that their occupants have incentives to give special attention to, and to advocate with special zeal, the interests of the persons or purposes that they are charged with representing. The general idea of a division of labour and special roles is familiar in constitutional design, and could be applied more generally to any claim of future generations, but for reasons indicated earlier, the idea is more appropriately limited to claims related to their democratic capacities.

To protect future democratic capacities, we should therefore establish some institutions that create roles that give special attention to democratic potential of individuals or groups who are otherwise not represented, or not adequately represented. Even when the incentives operate more through conventional habit and social approval than in response to any explicit expectation of rewards or punishments, they can be nonetheless effective in an institutional context.

What kind of institutional roles could encourage representatives in the present to give more attention to the democratic fate of citizens in the future? The most natural place to start is with the paradigmatic representative institution - the legislature. The chief advantages of situating the role in the legislature are that the representatives would participate directly in the 
process of making laws and would be accountable to an electorate. But the role of a representative dedicated to future constituents does not fit comfortably into an assembly of representatives accountable to actual constituents. The conflict between what each role requires can be seen in the difficulties raised by proposals to create special representatives of the future. ${ }^{10}$ How many representatives should the future have? Because the numbers obviously cannot be proportional to the potential constituents, the proposals usually set an arbitrary quota, typically two. But apart from the objection that in such small numbers these representatives are not likely to have much influence, the arbitrary quota would undermine the principle of equal representation - which is part of the idea of democracy that the proposal purports to uphold. Although current systems do not consistently observe strict principles of equality, the deviations (such as racial redistricting) are justified on democratic principles (such as equal opportunity), and do not set a fixed number of seats in the legislature without regard to changes in the electorate.

An even more fundamental difficulty with these proposals is evident when we ask: what is the electorate to whom these representatives are accountable? One proposal would create a 'proxy electorate' consisting of members of groups committed to 'environmental sustainability' (Dobson 1996, pp.132-5). But as a critic points out, the goals of such groups do not encompass all or even the most important interests of future generations (Ekeli 2005, pp. 148-9). In any case, environmental groups differ among themselves. Also, the proposal does not respect the right to equal votes: it would give members of the proxy electorate two votes each and other citizens only one each. On an alternative proposal (presented by the critic) each citizen would have two votes, one to cast for ordinary representatives and another to cast for special representatives dedicated to future citizens (so called F-representatives). Any group or party that legitimately is devoted to the interests of future generations could put forward candidates for the reserved positions in the 
legislatures. These 'F-representatives' would have a suspensive veto. To make sure that political groups and parties would not abuse the two-vote system (for example, by strategically running candidates in both campaigns), the government would strictly regulate which groups and candidates could qualify as legitimate representatives of the future.

The basic problem with these proposals — and any similar efforts to combine in one body a representational role that has constituents with one that does not-is that they assume that to be legitimate the representatives of the future must be as much like ordinary representatives. But the attempt to make the role of the future representatives replicate as far as possible the role of the ordinary representative is bound to fall short, and consequently destined to undermine the legitimacy of the future representatives. In trying to restore one democratic element to the role (accountability), the proposals inevitably sacrifice another (equal votes or free association). Instead of trying to square the representational circle by putting future representatives in the legislature, we should face up to the fact that they cannot have constituents in any normal sense. We should consider alternatives that model their roles more on those of trustees who are able to act independently, capable of influencing ordinary politics but free of the constraints that produce its presentism.

\section{Democratic futures: what duties trustees should have}

We may take some guidance from an ancient institution, the Tribune of the Plebs (tribunus plebis) in the Roman Republic (Cornell 1995, pp. 259-61; Staveley 1953, pp. 30-60; Homo 1996). Standing apart from ordinary politics but ready to intervene to defend the interests of a class otherwise unrepresented in politics, the Tribune in several key respects exemplifies the kind of institution that could provide representation for future generations. At the height of its power, it could intercede in judicial proceedings, and could veto legislative acts, and force the legislative 
consideration of its own proposals. Its only mission was to protect the rights and interests of plebs. Although elected (in the plebeian assembly) for fixed and usually non-renewable terms, the tribunes were accountable to no one but themselves while in office. The role of the tribune does not of course provide an exact model. The constituents whom the tribunes represented did actually exist, even though for the purposes of legislation they were an abstract class. Some of their powers - to impose capital punishment on anyone who interfered with their duties - may be somewhat excessive for our purposes. But several elements of the role are worth retrieving: a specialized duty toward the unrepresented, independence from other political authorities, and specific powers over the legislative agenda. The tribunes themselves should be public figures who had no political ambitions, except those that could confer (in Hobbes' terms) 'fame after death' (Hobbes 1991, I, xi).

The closet modern analogues are independent commissions and citizens assemblies. The advantage of a commission is that it makes possible the appointment of experts, persons with experience in promoting the interests of future generations. To realize this advantage, the appointment procedures would have to be designed to prevent the commission's capture by partisans of presentism. But even so, the commission's advantage is also its disadvantage: the special qualifications would set the members apart from ordinary citizens (not only present but also future). The members would be doubly deprived of democratic legitimacy: not only would they be unaccountable but they would be unlike the constituents they represent.

Although the lack of accountability cannot be avoided, the lack of resemblance can be diminished by the institution of a citizens' assembly. The members are ordinary citizens, and therefore more plausibility seen as surrogates for the ordinary citizens of the future (though of course no one can be sure what ordinary citizens will be like in the distant future). This institution too has ancient antecedents, but in modern times is relatively rare and only recently used at the 
level of national politics. The most promising examples are the assemblies created to consider reforms of the electoral systems in several Canadian provinces. In British Columbia, some 60 citizens, chosen more or less randomly, met weekly for nine months to decide whether to recommend a change in the provincial electoral system, and if so what new system to recommend (Thompson forthcoming). The recommendation in this case went to a popular referendum, but in some other cases the recommendation may go to a legislature. By all accounts, nearly all the members became remarkably competent in the technical and broader political aspects of electoral systems, and more importantly managed to rise above parochial concerns and concentrate on the long-term public good of the province. When it works well as it did in this case, a citizens' assembly provides a greater degree of legitimacy than a commission, and with little sacrifice of expertise.

In either of its forms - commission or assembly — an office of trusteeship could be established not only at the national but also at the international level. Because, as I emphasized earlier, national boundaries are less significant the further we look into the future, an international trustee would be eventually necessary, even if currently difficult to implement. Some of the proposals to establish a 'guardian' for future generations under the auspices of the United Nations would create an office that could in effect serve as a trustee (see for example Bruce 1998). Although when formally proposed at the UN, they are always blocked by member nations (Malhotra 1998, pp. 48-9). But none of the objections the opponents raise undermine the principled reasons for institutionalizing in an international body a greater concern for future generations. Some of the objections, however, point to legitimate questions about the responsibilities such a body should have. Proponents of a UN guardian differ among themselves about whether there should be one office or several offices each for different issues, and about what issues the office or offices should address (Stone 1998, pp. 65-79). ${ }^{11}$ Some of these 
disagreements and even some of the opposition could be ameliorated if the guardian is conceived as a trustee for the democratic process.

Whether at the national or international level and whether in the form of a commission or an assembly, these trustees should have some specific powers beyond the important duty of speaking for the interest of future generations in sustaining a robust democratic process. To indicate the range of possibilities, I mention some examples of such powers. (These are intended as merely speculative gestures, not concrete proposals.)

Suspensive Interventions. The Trustees would have the authority to stop temporarily actions by the legislature or executive that could be shown seriously impair the capacities of the democratic process in the future. Their authority could be limited to challenges to political procedures - for example, claims that the current legislature or executive unduly limited the discretion of future majorities. The Trustees would not have the authority on their its own to overrule the legislature or the executive. Their challenge would have to be reviewed by an independent judiciary. The power to overrule would be less important than the power to challenge. The Trustees could create an official and prominent forum for deliberating about the effects of current constraints on the democratic capacities of future sovereigns.

Posterity Impact Statements. The Trustees would require governments to issue statements justifying any adverse effects their actions might have on the democratic capacities of future citizens. (These statements are analogous to the environmental impact assessments, now required in the U.S. and European Union countries, which have been shown to be effective if properly administered (Glasson et al 2005, pp. 211-39; Tzoumis and Finegold 2000, pp. 557-78; Dayton 2002, pp. 355-405). Governments would have to show that their actions were necessary to implement the will of current citizens, and that no other actions less restrictive of future citizens could achieve this end at reasonable cost. The statement would have to be defended before an 
independent authority, perhaps the trustees themselves. The main advantage would be the effect on representatives and other officials, who in making decisions and enacting laws would know that they would have to defend them before other representatives (the Trustees) who care more about the future than the present. The subsequent deliberation - and therefore, in anticipation, the prior action - would be more likely to be more favourable to future citizens than it would have otherwise been.

Democratic Balance Sheets. Extending the idea of the impact statements, the Trustees could require governments at all levels to report annually the gains and losses in democratic control experienced by their agencies. The reports would be combined to publicize a 'democratic deficit' (or, probably more rarely, a 'democratic surplus'). The aim, as with the impact statements, would be to focus public attention on the question of whether the government is improving the capacity of the people in the future to control their own destiny. Like the budget deficit, the democratic deficit would reflect not only the current condition of the process, but also its future capacity. It would display the state of health of the democratic process that the current citizens leaves for future citizens.

Age-Differentiated Political Rights. The Trustees could seek legislation to enhance the political rights of future citizens. Several schemes for changing the distribution of electoral power to give future citizens more power have already been proposed. Limiting the voting age at the top (instead of only at the bottom) and giving parents extra votes may shift the balance of power, and therefore the perspectives of representatives (see, for example, Van Parijs 1998). These schemes do not directly address the problem of distant future generations. They are intended chiefly to ameliorate the tendency toward presentism in the relations between generations that live at the same time. But they could nevertheless serve an important expressive purpose for future generations. They convey the institutional message that representatives should look beyond the 
present; they would help develop a culture of more forward-looking representation. Even though representatives would still be responding to actual constituents, they would begin to attend more often to the interests of future constituents, and in particular their political rights.

Contingency Trust Fund. When governmental officials fail to protect the political interests of future generations (whether through negligence or necessity), the Trustees could require the government to provide compensation for the damage done to the democratic process. The compensation would go not to individuals but rather to a trust fund administered by the Trustees.

Generally, the grants would be dedicated to improving the democratic process - correcting defects in voting systems, for example. For major problems, the fund would probably be too small to provide adequate compensation. Additional revenues would have to be sought from the legislature. But even if the amounts were small, the symbolic value would be significant. Present democratic representatives would be held retrospectively responsible for the effects of their actions on future democratic representatives.

Constitutional Conventions. One important way the democratic capacities of future citizens can be diluted is by entrenched political constraints (such as constitutional prohibitions) that make it difficult for representatives to respond to social and technological changes. The Trustees could from time to time recommend the calling of a constitutional convention in order to keep the government and its constitution in sync with the changing circumstances and needs of its citizens. Such a power could enable a current generation to overcome the dead hand of the past, and reclaim its capacity for competent control. To be sure, many observers are thankful that the convention route to amending the U.S. constitution has never been used. ${ }^{12}$ The fear of a runaway convention is strong among both liberals and conservatives. But any constitutional convention the Trustees would recommend should be strictly limited so as to ensure that delegates could deal only with provisions that affect the democratic process (such as voting). 
Other limitations would include strict qualifications for the delegates, who should be respected citizens with no special attachments to the special interests or the partisan loyalties of a current generation. They too would care only about 'fame after death'.

International Collaboration. The Trustees of each nation would have the power (subject to approval by domestic legislatures) to enter into agreements with their counterparts in other nations to promote the democratic capacities for future citizens without regard to national boundaries. Because national governments may understandably have more concern for their own present (and immediate future) citizens, the Trustees may find more helpful allies in extragovernmental organizations. Strengthening international associations would help respond to the diminishing significance that national boundaries should have the further one looks into the future. A more robust international civil society, especially if populated by groups with long term aims such as preserving the environment and strengthening democratic institutions, would be more likely than most governments to give future sovereigns their due. ${ }^{13}$ International NGOs do not assume, as most representatives of governments tend to assume, that the most important consideration is the welfare of citizens in some particular state. This is partly because they are often more cosmopolitan in their outlook with respect to present generations. But the deeper reason they must be more cosmopolitan — not always appreciated by the NGOs themselves — is that the future generations they seek to benefit cannot be located now in any particular state. The distribution of neither future harms and benefits, nor future citizens themselves, will track the contours of present national boundaries.

\section{Conclusion}

Hobbes wrote that man is endowed with 'notable multiplying glasses,' which enlarge his own desires and accomplishments compared to those of others (Hobbes 1991, II, xviii). The same may 
be true of generations: the desires and accomplishments of our own generation loom larger in our field of vision than do those of the generations that will come later. Democratic trusteeship prescribes the institutional equivalent of bi-focals: citizens and their representatives today should be able to see clearly not only their own democratic needs but also those of future citizens. We need new institutions, or new devices within old institutions, to provide the clearer perspective that would extend our democratic vision.

\section{Notes on contributors}

Dennis Thompson is Alfred North Whitehead Professor of Political Philosophy at Harvard

University. His books include: Restoring Responsibility: Ethics in Government, Business, and

Healthcare; Just Elections: Creating a Fair Electoral Process in the United States; Political

Ethics and Public Office; Why Deliberative Democracy? (with Amy Gutmann); and Democracy

and Disagreement (with Amy Gutmann).

\section{References}

Aristotle, 1967. Politics. trans. H. Rackham, Cambridge Mass.: Harvard University Press.

Barry, B.M., 1989a. Justice between generations. In: B.M. Barry Democracy, Power and Justice Oxford: Clarendon Press, 494-510.

Barry, B.M., 1989b. Theories of justice. Berkeley: University of California Press.

Beckerman, W. and Pasek, J., 2001. Justice, posterity, and the environment. Oxford: Oxford University Press.

Biddle, B.J., 1986. Recent Developments in Role Theory. Annual Review of Sociology 12, 67-92.

Broome, J., 1992. Counting the cost of global warming. Cambridge: White Horse Press.

Bruce, M., 1998. A draft instrument establishing the role of a guardian. In: E. Agius and S. Busuttil, eds. Future generations and international law. London:

Earthscan, 163-65. 
Caplan, R., 1988. Constitutional brinksmanship: amending the constitution by national convention. New York: Oxford University Press.

Chandler, D., 2004. Constructing global civil society: morality and power in international relations. London: Palgrave Macmillan.

Cornell, T.J., 1995. The beginnings of Rome. London: Routledge.

Cropper, M., Aydede, S. and Portney, P., 1992. Rates of Time Preference for Saving Lives. American Economic Review, 82, 469-472.

Cropper, M., Aydede, S. and Portney, P., 1994. Preferences for life saving programs: how the public discounts time and age. Journal of Risk and Uncertainty, 8, 243-65.

Dayton, D., 2002. Evaluating environmental impact statements as communicative action. Journal of Business and Technical Communication, 16, 355-405.

De-Shalit, A., 1995. Why posterity matters: environmental policies and future generations. London: Routledge.

Dobson, A., 1996. Representative democracy and the environment. In: W.M. Lafferty and J. Meadowcroft, eds. Democracy and the environment. Cheltenham, UK: Edward Elgar, 124-39.

Ekeli, K.S., 2005. Representative Democracy and Future Generations. In: Democracy unbound: basic explorations, Stockholm Studies in Democratic Theory, 1, Stockholm: Stockholm University, 141-65.

Fafard, P. and Reid, D.R., 1991. Constituent assemblies: a comparative survey. Kingston, Ont.: Institute of Intergovernmental Relations, Queen's University.

Frederick, S., 2003. Measuring intergenerational time preference: are future lives valued less?. Journal of Risk and Uncertainty, 26, 39-53.

Gehlbach, H., 2004. A new perspective on perspective taking. Educational Psychology Review, 16, 207-34.

Glasson, J., Therivel, R. and Chadwick, A., 2005. Introduction to environmental impact assessment, $3^{\text {rd }}$ edition. Abingdon, UK: Routledge.

Hobbes, T., 1991. Leviathan, ed. R. Tuck, Cambridge: Cambridge University Press.

Homo, L., 1996. Roman political institutions. London: Routledge.

Ilgen, D.R. and Hollenbeck, J.R., 1991. The structure of work: job design and roles. In: M.D. Dunette and L. M. Hough, eds. Handbook of industrial and organizational psychology, 
vol. 2. Palo Alto, California: Consulting Psychologists Press, 165-207.

Johannesson, M., 1997. Saving lives in the present versus saving in the future - is there a framing effect?. Journal of Risk and Uncertainty, 15, 167-76.

Keane, J., 2003. Global civil society? Cambridge: Cambridge University Press.

Kumar, R., 2003. Who can be wronged?. Philosophy \& Public Affairs, 31, 99-118.

Laslett, P. and Fishkin, J., eds., 1992. Justice between age groups and generations. New Haven: Yale University Press.

Laslett, P., 1992. Is There a Generational Contract?. In P. Laslett and J. Fishkin, eds. Justice Between Age Groups and Generations, New Haven: Yale University Press, 25-47.

Locke, J., 1965. Two Treatises of Government, ed. Peter Laslett, New York: New American Library.

Malhotra, A., 1998. A commentary on the status of future generations as a subject of international law'. In: E. Agius and S. Busuttil, eds. Future generations and international law. London: Earthscan.

Mill, J.S., 1977. Considerations on Representative Government. In: J.M. Robson, ed., Essays on Politics and Society, Collected Works. Toronto: University of Toronto Press.

Parfit, D., 1983. The further future: the identity problem. In: D. MacLean and P. G. Brown, eds., Energy and the future. Totowa, NJ: Rowman and Littlefield, 166-179.

Parfit, D., 1986. Reasons and persons. Oxford: Oxford University Press.

Pitkin, H., 1967. Concept of representation. Berkeley: University of California Press.

Rawls, J., 1971. A theory of justice. Cambridge, MA: Harvard University Press.

Rawls, J., 1993. Political liberalism. New York: Columbia University Press.

Rawls, J., 2001. Justice as fairness: a restatement, ed. E. Kelly, Cambridge, MA: Harvard University Press.

Ryberg, J., et al., 2006. The repugnant conclusion. The Stanford Encyclopedia of Philosophy, ed., Edward N. Zalta, at <http://plato.stanford.edu/archives/spr2006/entries/repugnantconclusion $/>$.

Sikora, R.I. and Barry, B.M., eds. 1979. Obligations to future generations. Philadelphia: Temple University Press.

Simmons, P.J., 1998. Learning to live with NGOs. Foreign policy, 112, 82-96.

Slaughter, A.M., 2004. A new world order. Princeton, NJ: Princeton University Press). 
Staveley, E.S., 1953. The significance of the consular tribunate. Journal of Roman Studies, $43,30-60$.

Stone, C., 1998. Safeguarding future generations. In: E. Agius and S. Busuttil, eds., Future generations and international law. London: Earthscan.

Strijbos, J.W., et al. 2003. The effect of roles on group efficiency. In: B. Wasson, et al., eds., International conference on computer support for collaborative learning. Bergen: Intermedia.

Thompson, D., 2004. Restoring responsibility. Cambridge: Cambridge University Press.

Thompson, D., Forthcoming. Who should govern who governs? The role of citizens in reforming the electoral system. In: Mark Warren, ed., Theorizing the B.C. citizens assembly and beyond.

Tzoumis, K. and Finegold, L., 2000. Looking at the quality of draft environmental impact statements over time in the United Sates. Environmental Impact Assessment Review, 20, 557-78.

Van Parijs, P., 1998. The disfranchisement of the elderly, and other attempts to secure intergenerational justice. Philosophy \& public affairs, 27, 292-333.

Weber, P. and Perry, B., 1989. Unfounded fears: myths and realities of a constitutional convention. New York: Greenwood Press.

${ }^{1}$ One of the most influential surveys of time preferences found that "people attach less importance to saving lives in the future than to saving lives today'. See Cropper et al. 1992 and 1994. Subsequent studies have shown that at least some of the heavy discounting of future lives is due to framing effects and other variations in the questions asked in the surveys. See Johannesson 1997 and Frederick 2003.

2. The earliest version of this rationale was presented by Aristotle in what is sometimes called the 'shoes-pinching argument'. (Aristotle 1967: Bk. III, 128.b24).

3. For a sample of various philosophical approaches to the problem of future generations, see Sikora and Barry 1979; Barry 1989a; Laslett and Fishkin1992; De-Shalit1995; and Beckerman and Pasek 2001.

${ }^{4 .}$ See for example Laslett 1992.
} 
5. It is true that we do not know what the precise tastes of our remote descendants will be, but they are unlikely to include a desire for skin cancer, soil erosion, or the inundation of all low-lying areas as a result of the melting of the ice-caps' (Barry 1989a: 500).

${ }^{6}$. The most trenchant discussion of this general problem is in Barry 1989a: 496-510. On the problem of the identity of future persons, see Parfit 1983 and 1986: 351-453.

7. Choosing a just savings rate or even a discount rate for the distant future is notoriously difficult. See for example Broome 1992; and Barry 1989a: 502-506.

${ }^{8 .}$ This argument for a just savings principle was already present in certain passages in the statement of Rawls's initial theory: the principle, Rawls writes, is partly based on 'an estimate that seems fair from both sides, with due allowance made for the improvement in their circumstances...' (1971: 289).

9. For a proposed escape from the problem, see Kumar 2003.

10. Two of the most specific proposals for legislative representation are: Dobson 1996; and Ekeli, 2005. Ekeli presents his more developed proposal partly in critical response to Dobson's.

11. Stone provides the most systematic set of questions that any proposed reform of this type would have to address.

12. On the risks and benefits of constitutional conventions (or constituent assemblies), see Fafard and Reid 1991;

Weber and Perry1989; and Caplan1988.

${ }^{13 .}$ For recent views of the prospects for international civil society, see Keane 2003; Chandler 2004; and Slaughter 2004, esp. pp. 131-65. Specifically on NGOs (with a useful bibliography) is Simmons 1998. 